\title{
A ESTRUTURA TEÓRICO-DOGMÁTICA DO EQUILÍBRIO CONTRATUAL NO DIREITO PRIVADO - PODE SER ELE CONSIDERADO UM PRINCÍPIO GERAL DO DIREITO?
}

\author{
THE THEORETICAL-DOGMATIC STRUCTURE OF \\ CONTRACTUAL BALANCE IN PRIVATE LAW - MAY IT BE \\ TAKEN AS A GENERAL PRINCIPLE OF LAW?
}

Juliano Heinen

Procurador do Estado do Rio Grande do Sul. Doutor em Direito Público - Universidade Federal do Rio Grande do Sul (UFRGS). Professor de Graduação e Pós-Graduação na Fundação Escola Superior do Ministério Público (FMP). Professor de Pós-Graduação em diversas universidades e instituições, destacando-se a Escola Superior da Magistratura Federal (Esmafe) e a Escola Superior da Magistratura Estadual (Ajuris). Site: www.julianoheinen.com.br.

Leonela Otilia Sauter Soares

Mestra em Direito pela Universidade Federal do Rio Grande do Sul - UFRGS, vinculada ao Centro de Estudos Europeus e Alemães - CDEA (convênio UFRGS/PUCRS/DAAD. Pós-Graduada em Direito Público pela Esmafe-RS. Graduada em Ciências Jurídicas e Sociais pela UFRGS.

Resumo: Este trabalho analisa a estrutura dogmática do princípio do equilíbrio contratual no direito privado. Para tanto, são examinadas as teorias clássicas do tema, a saber: a teoria da base do negócio jurídico, a teoria da imprevisão e a teoria da onerosidade excessiva, examinadas pela sua relevância internacional e influência no cenário brasileiro. Em seguida, trata-se dos arts. 317 e 478 do Código Civil brasileiro, para se verificar se há ou não um princípio geral do equilíbrio contratual. Quanto ao método, a abordagem do tema é dedutiva; o procedimento empregado na investigação é analítico; enquanto a técnica de pesquisa é bibliográfica e documental.

Palavras-chave: Revisão contratual. Onerosidade excessiva superveniente. Contratos empresariais.

Abstract: This paper analyzes the dogmatic structure of the principle of contractual equilibrium in private law. In order to do so, the classical theories of the subject are examined, namely, the theory of the base of the juridical business, the theory of the imprecision, and the theory of supervening excessive burden, examined by its international relevance and influence in the Brazilian scenario. Next, the articles 317 and 478 of the Brazilian Civil Code are verified, in order to check whether there is a general principle of contractual equilibrium. As for the method, the approach of the theme is deductive; 
the procedure used in the investigation is analytical; while the research technique is bibliographical and documentary.

Keywords: Contractual review. Supervening excessive burden. Business contracts.

Sumário: Introdução - 1 Mecanismos de reequilíbrio dos contratos empresariais presentes na dogmática estrangeira - 2 A revisão contratual no Código Civil brasileiro - 3 A onerosidade excessiva como um princípio geral do direito - Conclusão

\section{Introdução}

O tempo do direito "torna-se" um tempo sempre provisório e promitente, sobretudo, para o tempo presente e futuro, este marcado pelas características da indefinição e indeterminação, ainda que também pelo tempo da promessa. ${ }^{1}$ Como expoente desta promessa feita pelo direito, o contrato é uma instituição que promete um futuro: o cumprimento daquilo que foi avençado. É típica modalidade normativa destinada à apreensão do futuro jurídico, porque se compromete a deixar o presente negociado intacto. ${ }^{2} \mathrm{E}$, neste momento, quando o contrato dura no tempo, ou seja, não se implementa instantaneamente, é que o próprio tempo passa a ser seu maior inimigo.

Neste ínterim, entre a feitura do contrato e seu adimplemento final, a realidade pode cambiar, alterando não só a conjuntura entre os contratantes, mas atingindo também a base econômica sob a qual se erigiu o negócio. Então, o direito passa a atuar "contra a realidade presente", a fim de reconduzir as partes, ainda que minimamente, ao passado em que se firmou o ajuste. Em outras palavras, pretende retomar o mesmo equilíbrio de outrora. ${ }^{3}$ Neste contexto surgem os mecanismos que procuram, cada qual ao seu modo, reconduzir as partes contratantes ao equilíbrio contratual que, no presente, já não mais existe por uma série de fatores.

1 “Talvez seja preciso evocar aqui o enigmático ‘pequeno corcunda' de que falava Walter Benjamin: esse estranho e insistente passado que não pára de nos interpelar. 'Quanto menos vemos o pequeno corcunda, escrevia ele, mais ele olha para nós’, E esse olhar, pressentimo-lo, é por vezes o olhar da censura. Pelo menos uma parte do passado acusa-nos, ou pelo menos lembra a dívida contraída em relação aos marginalizados, ou até as vítimas da nossa história. Eis, pois, que a relação com a tradição se complica: já não se trata apenas de recolher os dividendos do passado, mas também pagar as dívidas que aí foram contraídas" (OST, François. O tempo do direito. Lisboa: Instituto Piaget, 1999. p. 159).

2 MARTINS-COSTA, Judith. A cláusula de hardship e a obrigação de renegociar nos contratos de longa duração. Revista de Arbitragem e Mediação, São Paulo, v. 25, abr./jun. 2010. p. 11.

3 O contrato pretende "[...] estabelecer a dominação da vontade humana sobre os fatos, integrando-os num ato de previsão" (LÉCUYER, Hervé. Le contrat, acte de prévision. L'avenir du droit: mélanges em Hommage a François Terré. Paris: Dalloz, 1999. p. 643). 
Para tanto, analisar-se-ão, por meio do método de abordagem dedutivo e por meio do método de procedimento analítico, em um primeiro momento, as premissas dogmáticas de três teorias que propugnam, cada qual ao seu turno, manter o equilíbrio econômico-financeiro de um contrato: a teoria da base do negócio jurídico, a teoria da imprevisão e a teoria da onerosidade excessiva. Estudar-se-ão estas três teorias oriundas da dogmática estrangeira por dois motivos principais: pela sua relevância no cenário mundial, bem como por influenciarem a dogmática nacional e, de quebra, o sistema jurídico-positivo.

Em um segundo momento, também de modo analítico, será exposta a perspectiva nacional sobre o tema. Ainda, de modo comparativo, esta matriz científica será confrontada com as teorias expostas na primeira parte do trabalho. Assim, será exposto como se opera a revisão contratual no Código Civil, destacando-se a análise dos arts. 317 e 478 , seja no que se refere aos requisitos explícitos, seja no que tange aos requisitos implícitos.

A partir da matriz teórico-dogmática enfrentada, que se pauta na compreensão do binômio equilíbrio-tempo, deverá ser percebido, por dedução e de modo dissertativo, se a onerosidade excessiva pode ser considerada um "princípio geral do direito", como ocorre, por exemplo, com a figura do "enriquecimento sem causa", ou com a premissa de que "ninguém pode se beneficiar da própria torpeza" etc. Enfim e mais especificamente, se a ideia de equidade pode ser invocada em qualquer contrato de direito comum, independentemente do alcance do direito positivo, ou mesmo presente, mas de modo insuficiente.

O tema passa pela discussão sobre se a categoria de negócio jurídico ainda abarca todas as espécies de contratos (se ainda é útil) e se temos uma teoria geral dos contratos que explique todos os fenômenos. Contudo, isto não será objeto da presente abordagem, porque renderia, pela sua complexidade, um trabalho único. ${ }^{4}$

\section{Mecanismos de reequilíbrio dos contratos empresariais presentes na dogmática estrangeira}

Ainda que esta seja uma visão mais "filosófica" do tema, é certo que, em última análise, os mecanismos de reequilíbrio dos contratos possuem como finalidade recompor uma realidade alterada pelo tempo. E, para tanto, quando o direito atua sobre o tempo - tentando vencer sua lógica e sua adequação natural -, deve

\footnotetext{
4 Sobre a rediscussão da categoria de negócio jurídico, conferir a obra de Teresa Negreiros e de Cristiano de Sousa Zanetti (Direito contratual contemporâneo: a liberdade contratual e sua fragmentação. São Paulo: Método, 2008, passim).
} 
se valer da "força". ${ }^{5}$ Então, tais mecanismos pretendem, também em uma análise finalística, conferir previsibilidade e segurança às relações negociais. ${ }^{6}$

Existem relações que dependem do tempo, porque a execução da prestação depende do transcurso de lapso temporal. Há inúmeras obrigações duradouras no direito civil: relações familiares, contratuais, sucessórias etc. Não é só nos contratos que o tempo ganha relevância, fazendo parte substancial do suporte fático, mas também faz parte de outras relações no direito. 0 tempo é fundamental em diversos institutos que o pressupõem, constituindo parte do suporte fático. Como exemplo, tem-se o testamento, a doação onerosa, a prescrição, a decadência. Inclusive os contratos fazem parte dessa categoria, pois tentam "domar" o tempo, seja antecipando seja tentando estabilizar relações futuras. Desta forma, ao firmar contrato de locação ou de comodato, quer-se garantir que o uso de um imóvel seja mantido por lapso de tempo.

A influência temporal também pode ser verificada na simetria da relação entre as partes. 0 contrato pode iniciar simétrico e, com o decorrer da relação, a "balança" vir a se desequilibrar, configurando uma desigualdade. Veja o que ocorre com o contrato de distribuição ou o de representação: no início da relação contratual, o fornecedor do produto depende do representante para propagar a sua marca e bem comercializar o produto. Contudo, quando a marca já é apresentada e conhecida, a relação de dependência se inverte, sendo que é o representante que passa a depender do fornecedor. Por isto que, neste caso, a denúncia imotivada precisa ser remunerada (compensada). A proteção jurídica do contrato de distribuição e de representação deve ser diferente, porque a economia destes negócios é completamente diversa.

O efeito do tempo possui relevância também à onerosidade excessiva, não prevista no contrato. Até porque ela pode atingir qualquer contrato que não seja instantâneo. No caso, na revisão da prestação diferida - que precisa de um tempo para ocorrer (vide empreitada) - a onerosidade é analisada ex tunc. No entanto, nos contratos de longa duração, a onerosidade operará prospectivamente (ex nunc).

Os contratos vivem um paradoxo: ao mesmo tempo que se fazem contratos para se ter certeza, estes "são lançados" 7 em um mundo de incertezas, porque

5 Uma explicação bastante didática sobre esta relação entre o "tempo", o "direito" e a "força” pode ser conferida a partir da relação feita por François Ost (O tempo do direito. Lisboa: Instituto Piaget, 1999. p. 9-10) para com o "mito de Cronos".

6 Afinal, não é outra senão uma das finalidades do direito, qual seja, conferir previsão, o que é ínsito em relação ao contrato. Logo, as partes contratantes logram em aceitar uma promessa de que as coisas sejam cumpridas de determinada maneira em certo tempo.

7 "Alea iacta est": a frase atribuída a Júlio César ao decidir cruzar com suas tropas o Rio Rubicão tem pleno paralelo com os contratos, pois, por melhores e mais amplas que sejam as previsões contratuais, nem todos os âmbitos serão cobertos e todo o contrato estará sujeito a riscos em alguma medida. 
não se sabe como este mundo se comportará em relação a eles. Assim, é uma ilusão pensar que esta estabilidade será fixa. 0 que se deve ter são bases estruturadas para que se possa dar flexibilidade para os câmbios futuros da realidade. Os próprios contratantes não querem esta inflexibilidade, porque, se assim fosse, estar-se-ia aniquilando a autonomia da vontade.

Aliás, nesse aspecto, importante notar que o adimplemento é elemento polarizador do tempo das obrigações, o que não se vê nas relações de direito real. Até porque, no primeiro caso, a satisfação opera-se por colaboração, enquanto, nas segundas, opera-se por sujeição. Neste último caso, o titular necessita apenas da abstenção dos demais. Exemplo: o proprietário se satisfaz com o uso, gozo etc. do bem de que é dono. E isto tem reflexos marcantes no âmbito do processo civil, especialmente diante da fase de cumprimento de sentença. ${ }^{8}$

Nos contratos duradouros, que excedem o adimplemento, percebe-se um "renascer" das pretensões, porque reclamam reiterada satisfação. ${ }^{9}$ Assim, a execução, aqui, excede, de forma muito clara, a sua formação. 0 tempo, então é relevante no plano da eficácia das obrigações.

Assim, antes de perceber as premissas dogmáticas de três das principais teorias acerca do tema, bem como visualizar a perspectiva nacional sobre o reequilíbrio, mostra-se essencial compreender que há premissas epistemológicas no que se refere aos mecanismos de reequilíbrio contratual, bem como em relação às teorias a serem abordadas.

A rigor, não se pode compreender o assunto sem partir da premissa de que as obrigações possuem base teórico-dogmática no binômio equilíbrio-tempo, porque se desenvolvem em um "processo" ${ }^{10} \mathrm{E}$ isto se reflete com muita ênfase nos contratos empresariais. Este processo, que pode durar no tempo, reclama toda sorte de confiança em relação às partes que negociam.

Assim, a necessária busca dos traços comuns dos contratos mercantis ${ }^{11}$ envolve pensar que eles buscam o lucro, possuindo nítida função econômica. Em verdade, há custos de transação na prática de contratos empresariais, a serem sopesados com fatores ligados ao oportunismo e à vinculação. Assim, estes fatores possuem efeitos essenciais quando se pretende promover o reequilíbrio

8 No campo obrigacional, a sujeição perpétua somente se daria se fosse estabelecido um vínculo de escravatura, o que é impensável.

9 E isto foi bastante influenciado na unificação das obrigações civis e mercantis no Código Civil italiano de 1943.

10 E, aqui, incidem com veemência as explicações de Clóvis do Couto e Silva feitas em: A obrigação como processo. São Paulo: FGV, 2006; e, mais especificamente, aquelas dispostas em: Teoria da base do negócio jurídico no direito brasileiro. Revista dos Tribunais, São Paulo, n. 79, v. 655, 1990. p. 7-8).

11 A análise das premissas dogmáticas dos contratos mercantis, ou seja, seus "traços comuns" foram expostos por Paula Forgioni no Capítulo II de sua obra específica sobre o tema: Teoria geral dos contratos empresariais. São Paulo: Revista dos Tribunais, 2009. p. 55 e ss., passim. 
contratual, mesmo porque uma das finalidades desta modalidade de ajuste é conseguir, entre os atores do livre mercado, segurança e previsibilidade. ${ }^{12}$

Em outros termos, a base jurídico-positiva que trata do tema, a seguir detaIhada, pode permitir e pretender uma revisão contratual com base na alteração dos custos de transação. ${ }^{13}$ Portanto, para se dar vazão ao reequilíbrio, pensa-se que a vontade individual deixa de atuar no primeiro plano da tutela jurídica, ou seja, autonomia privada passa a ser concebida como uma manifestação social derivada de fatos sociais, que são examinados e qualificados (juridicizados ou não) pela ordem jurídica, que é apenas fonte geradora da obrigação contratual. ${ }^{14}$ Assim que o negócio jurídico é uma qualificação concedida pelo direito a uma realidade que jamais perde seu caráter pré-jurídico, pois o negócio econômico, mesmo após a qualificação jurídica, nunca constitui um ente meramente formal.

As relações contratuais devem ter base na justiça comutativa, que serve para corrigir as desigualdades da justiça distributiva, ao se estabelecer trocas, recebendo bens que não tenho, e fornecendo outros a outrem que não os têm. Graças aos contratos que se consegue tomar posse de bens que não se tem, senão seria por desapropriação, requisição, doação do Estado, apropriando-se riqueza de forma distributiva.

Então, a revisão dos contratos que busca o seu reequilíbrio só faz sentido nos contratos de execução continuada ou diferida, ou nos contratos de duração.

Da mesma forma, independentemente da teoria a ser aplicada, se o contrato já foi cumprido, a revisão logicamente não pode ser pleiteada, porque ela justamente se presta a adaptar o contrato para ele ser cumprido. Se o contrato já terminou, pode-se somente pedir repetição de algo pago ilegalmente (exemplo: juros acima do legalmente admitido). Logo, em contrato extinto não cabe revisão. ${ }^{15}$

De outro lado, devemos considerar que a comutatividade e o sinalagma do contrato enaltecem a preocupação com a manutenção do equilíbrio. Aliás, a ideia de que o contrato visa à troca reclama o estudo da causa do contrato, como um parâmetro inicial ao debate acerca do reequilíbrio. ${ }^{16}$ Neste aspecto, a onerosidade

12 FORGIONI, Paula. Teoria geral dos contratos empresariais. São Paulo: Revista dos Tribunais, 2009. p. 75-78.

13 ROPPO, Vicenzo. Il contratto del duemila. Turim: Giappichelli, 2002. p. 134.

14 GATTI, Serafino. L'adequatezza fra le prestazione nei contratti com prestazione corripettive. Rivista di Diritto Commerciale, ano LXI, n. 11-12, p. 424-463, nov./dez. 1963.

15 Na ótica dos autores deste artigo, quando o STJ decide que "A jurisprudência desta Corte é pacífica no sentido de ser possível a revisão de contratos bancários extintos, novados ou quitados, ainda que em sede de embargos à execução, de maneira a afastar eventuais ilegalidades, as quais não convalescem, a teor da Súmula 286 do STJ" (STJ, 4ª Turma. AgInt no AREsp nº 16.047-RJ. Rel. Min. Raul Araújo, j. 17.8.2017), está a se referir à repetição de algo pago ilegalmente.

16 Por todos: SILVA, Luís Renato Ferreira da. As causas de revisão do contrato pelo juiz e o Código de Defesa do Consumidor. Revista da Faculdade de Direito da UFRGS, Porto Alegre, n. 11, 1996. 
para uma das partes contratantes deve estar presente, e necessita causar le bouleversement de l'économie du contrat ${ }^{17}$ (uma perturbação à economia do contrato). Por fim, deve-se avaliar se não há imputabilidade do ônus a um dos sujeitos do negócio jurídico. ${ }^{18}$

\subsection{Teoria da quebra da base do negócio jurídico}

A teoria da quebra da base do negócio jurídico começa a ser estruturada no final do século XIX, e desenvolvida com mais ênfase até meados do século XX. ${ }^{19}$ Apesar disto, podemos ver uma aplicação interessante dela ainda no século XVII, na Inglaterra, no caso Paradine $v$. Jane (1647), no qual Paradine é locador de Jane, e propõe ação judicial alegando não pagamento de alugueres por três anos. Em sua defesa, a locatária alega que não utilizou o bem neste período, por conta da ocupação dele pelas forças inimigas do Rei Carlos I, ${ }^{20}$ durante a Guerra Civil inglesa (1642-1649). A Corte inglesa não acolheu a defesa de Jane, por conta de que a locatária também deveria suportar os lucros ou prejuízos inesperados.

No século XIX, a teoria da quebra da base do negócio é retomada no caso Taylor v. Caldwell (1863), momento em que o referido tribunal inglês refaz o entendimento de Paradine $v$. Jane (1647). No caso agora a ser julgado, um grupo de músicos fora contratado por uma casa de espetáculos para se apresentar por várias noites. Contudo, o local pega fogo, impossibilitando as ditas apresentações. Os músicos, então, demandam contra o proprietário, para cobrar o contratante. Neste caso, a corte judicial britânica entende que este último estava desobrigado ao pagamento.

Por fim, a Suprema Corte britânica ainda se vale da teoria nos coroation case's (exemplo: Krell v. Henry (1903)), nos quais certos contratados alegam prejuízos pelo cancelamento da coroação do Rei Eduard VII. Está-se diante de uma série de casos em que pessoas que haviam alugado cadeiras, janelas e embarcações para ver o cotejo de coroação do Rei Eduardo VII viram seu objetivo frustrado, pois a coroação foi adiada em razão de doença do monarca. Tais julgados são por deveras relevantes a estruturar uma base dogmática ao tema. ${ }^{21}$

CHAPUS, René. Droit administratif général. Paris: Montchrestien, 2001. t. 1. p. 1211.

18 SILVA, Luís Renato Ferreira da. Reciprocidade e contrato. A teoria da causa e sua aplicação nos contratos e nas relações “paracontratuais”. Porto Alegre: Livraria do Advogado, 2013. p. 96-97.

19 Não se confunde com os institutos da frustration, que é bem mais ampla, porque ligada à finalidade do contrato (propouse), nem com a impossibility.

20 O governo do Rei Carlos I durou de 1625 a 1649.

21 SILVA, Luís Renato Ferreira da. Reciprocidade e contrato. A teoria da causa e sua aplicação nos contratos e nas relações “paracontratuais”. Porto Alegre: Livraria do Advogado, 2013. p. 127-128; TREITEL, Guenter. H. Frustration and force majeure. London: Sweet \& Maxwell, 1994. p. 84. 
Na Alemanha, a teoria da quebra da base objetiva do negócio também se mostrou presente na resolução de determinadas controvérsias. Em 28.11.1923, o Tribunal Superior Alemão debatia a questão da distribuição dos prejuízos em caso de inflação. A corte decidiu que as partes eram, conjuntamente, credor e devedor, e, por isso, deveriam ambas arcar com os prejuízos ocasionados pela inflação, baseando sua sentença no §242 do Código Civil germânico (v.g. BGB). ${ }^{22}$

O substrato dogmático colmatado acabou por gerar, em verdade, duas teorias da quebra da base: a subjetiva e a objetiva. Sinteticamente, pode-se conceituar cada qual da seguinte maneira: (a) teoria da quebra da base subjetiva do negócio, que é fundada na "teoria da pressuposição" de Windscheid e aprimorada por Paul Oertmann, ${ }^{23}$ advoga que as partes possuem uma representação mental na hora da formação do negócio ("erro conjunto quanto aos motivos"). E, quando, no futuro, esta "representação" não se verifica, existirá uma quebra nesta "base subjetiva do negócio"; ${ }^{24}$ (b) teoria da quebra da base objetiva do negócio: desenvolvida por Karl Larenz. ${ }^{25}$ Deixa de dar ênfase ao motivo, para focar nas circunstâncias do negócio.

De modo bastante objetivo, podemos sintetizar os elementos dogmáticos da teoria da quebra da base objetiva em itens, a seguir dispostos: ${ }^{26}$

(a) Há de ocorrer um evento extraordinário, logo, é sensível ao caso a natureza das circunstâncias supervenientes;

(b) $O$ evento mencionado deve ter causado uma maior onerosidade a um dos contratantes, ou seja, deve-se perguntar se houve alteração significativa na economia contratual;

(c) A base negocial deve ter sido realmente atingida; [...].

A causa objetiva, ${ }^{27}$ no sentido de função econômica, releva a presença do transcurso do tempo. Contudo, a causa subjetiva pode variar para as partes, e, então, o tempo possui ou não relevância de modo também subjetivo. Ambas as partes devem ter interesse na duração, até porque a duração pode ser interessante para um, mas não para outro. Exemplo: no mútuo feneratício, a remuneração

22 Para a interpretação atual do §242 do BGB, ver: WESTERMAN, Harm Peter; GRÜNEWALD, Barbara; MAIERREIMER, Georg. Bürgerliches Gesetzbuch Handkommentar. Köln: Dr. Otto Schmidt, 2011.

23 OERTMANN, Paul. Rechtsordnung und Verkehrssitte. Insbesonders nach bürgerlichem Recht: Zugleich ein Beitrag zu den Lehren von der Auslegung der Rechtsgeschäfte und von der Revision. Amsterdam: Scientia, 1970.

24 RGZ 103, 328 (332).

25 LARENZ, Karl. Base del negocio jurídico y cumplimiento de RJLB. Albolote (Granada): Comares, 2002

26 SILVA, Luís Renato Ferreira da. Reciprocidade e contrato. A teoria da causa e sua aplicação nos contratos e nas relações "paracontratuais". Porto Alegre: Livraria do Advogado, 2013. p. 140-142.

27 O termo "causa objetiva", está disposto, aqui, no sentido de "função", e não de "motivo", que seria a causa subjetiva. 
não é elementar nesta espécie negocial, mas sim, o uso da coisa (v.g., posse). 0 contrato pode ter uma atividade-fim pontual ou duradoura, a depender do objeto do negócio jurídico. 0 que varia é a necessidade de uma mão de obra pontual ou duradoura.

Perceba que a teoria, para ser aplicada, não reclama que o evento seja imprevisivel, nem que esteja presente uma extrema vantagem para a outra parte (basta ser verificada a ocorrência da onerosidade excessiva). Em resumo, a referida teoria estabelece como requisito principal o desequilíbrio das prestações.

Para tanto, a jurisprudência alemã estabelece uma série de requisitos para a aplicação da teoria da quebra da base do negócio. Em outros termos, são hipóteses de desaparecimento da base do negócio em razão da subsequente modificação das circunstâncias derivadas de: perturbações na relação de equivalência; dificuldade extraordinária da prestação; frustração do escopo do negócio; modificações da legislação e da jurisprudência; desvalorização monetária; desvalorização da prestação em espécie (aumento do custo da prestação); ${ }^{28}$ excesso ou ultrapassagem do risco atribuído; intervenções de autoridades; perturbação ou frustração do objetivo da prestação.

Vamos a outro exemplo de aplicação da referida teoria na Alemanha. Certos proprietários da terra ingressaram em juízo contra a empresa mineradora detentora do direito de extração de salitre em determinada área, postulando revisão do contrato pelo aumento do valor do "aluguel" cobrado pela exploração da terra, uma vez que, com a virada do século XIX para o século XX, a quantia havia se tornado obsoleta, perturbando, assim, a base do contrato. 0 contrato previa 0 pagamento anual de uma quantia em dinheiro, em troca do direito da extração de minério em determinada área. 0 Bundesgerichtshof (BHB) entendeu que não assistia direito aos autores, uma vez que não havia se configurado o desequilíbrio entre prestação e contraprestação. Tal corte declarou que, ainda que o contrato tenha sido celebrado no ano de 1898 , se tratava de uma relação recíproca, e o valor pago como "aluguel", na quantia de um mil e duzentos marcos, por ano, na época, foi fixado de maneira arbitrária entre as partes, não tendo sido atrelado a nenhum tipo de variável, como o preço do salitre ou a sua quantidade extraída. Desta forma, entendeu-se que as modificações econômicas ao longo da execução do contrato não foram suficientes para gerar um grave abalo no equilíbrio do contrato, razão pela qual descabe a sua revisão para aumentar o valor do "aluguel". ${ }^{29}$

\footnotetext{
28 Exemplo: a produção do óleo para aquecimento sofreu um grave abalo no custo em decorrência da crise do óleo ocasionada pela Guerra do Yom Kippur, em 1973, pela não revisão de contratos de fornecimento de óleo para aquecimento urbano, firmado em 1972 (BGH, em 8.2.1978 - BB 1978, 1033).

29 BGH NJW 1959, 2203, julgado em 14.10.1959.
} 
De outro lado, as cortes alemãs reconhecem que houve quebra da base objetiva em: contratos de aluguel de longa duração ou na remuneração sobre o direito de superfície, quando o custo de vida tiver subido mais de cento e cinquenta por cento (150\%) entre o momento de celebração do contrato e o pedido de revisão. ${ }^{30}$

Atualmente, o Código Civil germânico prevê a possibilidade de alegar a quebra da base a partir de previsão expressa em seu texto, conforme alterações feitas pela Schuldrechtsmodernisierungsgesetz (lei para a modernização do direito das obrigações), conforme dispõe o $\S 313$ do BGB. Tal dispositivo permite a revisão contratual quando se perceber "perturbação da base do negócio", desde que ela seja grave (schwerwiegend) em três situações (de acordo com os três itens do dispositivo):

(a) Se circunstâncias, tornadas como base do contrato, se alteraram profundamente depois da sua celebração, de modo que as partes não o teriam celebrado ou o teriam com outro conteúdo, se houvessem previsto essa alteração, então pode ser exigida a revisão do contrato, na medida em que for inexigivel para a parte a manutenção do contrato não modificado, considerando todas as circunstâncias do caso concreto, especialmente a repartição contratual ou legal do risco. Aqui, deve-se notar que o dispositivo enfatiza a necessidade de alteração das circunstâncias, e trabalha com a distribuição de riscos;

(b) Da mesma forma, percebe-se uma relevante alteração das circunstâncias quando representações essenciais, que são parte da base do contrato, demonstrem-se falsas. Em verdade, tal dispositivo tutela o "erro de representação", positivando, pois, a "teoria da quebra da base subjetiva do negócio";

(c) Se não é possível a revisão ou se ela não for exigivel de uma das partes, então pode a parte prejudicada resolver o contrato. No lugar do direito de resolução, dá-se o direito à denúncia, nos casos de relações duradouras. ${ }^{31}$

No Brasil, a teoria da quebra da base objetiva do negócio foi incorporada pelo Código de Defesa do Consumidor (Lei no 8.078/90), no art. 6º, inc. V. ${ }^{32}$ Passemos ao estudo de outra teoria, oriunda da França.

BGH NJW 86, 168; BHB NJW 81, 1668

31 No que se refere aos contratos de direito público, o $\$ 313$ é aplicado apenas subsidiariamente, uma vez que há regra específica que tutela este tipo de negócio, qual seja, o §60 da VwVfG (Verwaltungsverfahrensgesetz, "Lei do Processo Administrativo", em tradução livre).

32 CDC, art. 6o: "São direitos básicos do consumidor: [...] V - a modificação das cláusulas contratuais que estabeleçam prestações desproporcionais ou sua revisão em razão de fatos supervenientes que as tornem excessivamente onerosas". 


\subsection{Teoria da imprevisão}

A teoria da imprevisão já era prevista no direito canônico, ${ }^{33}$ mas foi esquecida no auge do liberalismo (individualismo). Será retomada no final do século XIX e início do XX, no caso da Companhia de Gás de Bourdeaux, julgado pelo Conselho de Estado francês. Em outras palavras, a referida Corte francesa já dava mostras de aplicar tal teoria ainda em 1910, para presenvar a continuidade do contrato administrativo com a Cie. Générale française des Tranmways. Mas o caso emblemático da aplicação da teoria da imprevisão nos contratos administrativos pode ser conferido no caso da empresa de Bourdeaux, citado. ${ }^{34}$

É curioso notar que o desenvolvimento teórico-dogmático da teoria da imprevisão mostra-se latente nos contratos de direito público, sendo que o direito privado francês demora a incorporar esta teoria, mantendo a rigidez da pacta sun servanda. Mesmo a Lei de Falliot (de 1912), que permitia a resolução de contratos cujas prestações, em consequência da guerra, tornaram-se demasiadamente onerosas aos contratantes, apesar de fazer previsão expressa da possibilidade de revisão contratual, era basicamente casuística. Este fato revela a dificuldade do direito privado em incorporar tal substrato dogmático. Tanto que Ripert dizia que a Lei de Falliot era um atentado contra a autonomia da vontade e contra os redatores do Código Civil napoleônico. ${ }^{35}$

Assim, enquanto o direito público incorporou plenamente a mencionada teoria, o direito privado a previu, expressamente, em legislações específicas e muitas vezes casuísticas, como a Lei de 1919, que tratava sobre seguros; a Lei de 1924, sobre arredamento; a Lei de 1925, que tutelava preços de aluguéis. Todas elas são normativas emergenciais, sem que se produzisse uma "regra geral" sobre o tema.

Em termos dogmáticos, a teoria da imprevisão pressupõe a ocorrência de fatos imprevistos, ou previsíveis, mas de consequências imprevisíveis, enfim, ocorridos após a constituição do contrato, e alheios à vontade das partes, resultando em um ambiente econômico diverso. ${ }^{36} \mathrm{~A}$ definição da teoria pode bem partir da diç̧ão do art. 317 do CC:

Art. 317. Quando, por motivos imprevisíveis, sobrevier desproporção manifesta entre o valor da prestação devida e o do momento de sua

33 Muito embora a teoria da imprevisão já tenha reminiscências históricas no Código de Hamurabi.

34 CE, 30 mar. 1916, Cie. Génerale d'Éclairage de Bourdeaux, o conhecido "caso do gás de Bourdeaux".

35 RIPERT, Georges. A regra moral nas obrigações civis. Campinas: Bookseller, 2000. p. 145.

36 Sobre a teoria da imprevisão no direito administrativo, consultar a obra de Maria Sylvia Zanella Di Pietro (Direito administrativo. São Paulo: Atlas, 2015. p. 329). 
execução, poderá o juiz corrigi-lo, a pedido da parte, de modo que assegure, quanto possivel, o valor real da prestação. ${ }^{37}$

\section{Esse dispositivo deve ser conjugado com o art. 478 do mesmo código:}

Nos contratos de execução continuada ou diferida, se a prestação de uma das partes se tornar excessivamente onerosa, com extrema vantagem para a outra, em virtude de acontecimentos extraordinários e imprevisíveis, poderá o devedor pedir a resolução do contrato. Os efeitos da sentença que a decretar retroagirão à data da citação.

Enfim, trata-se da soma de um fato superveniente, com a ocorrência de uma onerosidade excessiva. ${ }^{38}$

Para tanto, uma soma de condições deve estar presente para que o contratante prejudicado possa pleitear medidas compensatórias: ${ }^{39}$

(a) O risco (álea) deve ser independente da vontade das partes e imprevisível, como no caso de guerra, grave crise econômica, desvalorização da moeda etc. Enfim, deve ser oriundo de acontecimento dificilmente resistível. Sendo assim, a causa da recomposição deve ser considerada imprevisível, ou previsível, mas de consequências imprevisiveis; ${ }^{40}$

(b) A onerosidade deve existir, ${ }^{41}$ mas não pode ser absoluta, ${ }^{42}$ e deverá ter um carácter temporário. Mas ela deverá existir, causando uma desproporção no sinalagma contratual;

37 Uma análise muito perspicaz sobre o tema foi feito em: ROCHA, Flávia Baldotto da; TRENTINI, Flávia. A possibilidade de revisão judicial das obrigações: art. 317 do Código Civil e o impacto da teoria da imprevisão no direito civil brasileiro. Revista Forense, Rio de Janeiro, v. 106, n. 407, p. 547-557, jan./fev. 2010.

38 Nas relações de consumo, a teoria foi adaptada no art. $6^{\circ}$, inc. $V$ do CDC, que dispensa a prova do fato imprevisível (diferentemente do que ocorre nas relações civis comuns, reguladas pelo CC). Assim, é suficiente a existência de um acontecimento superveniente que gere o desequilíbrio negocial: "São direitos básicos do consumidor: [...] V - a modificação das cláusulas contratuais que estabeleçam prestações desproporcionais ou sua revisão em razão de fatos supervenientes que as tornem excessivamente onerosas; [...]" - Lei no 8.078/90.

39 BITTAR FILHO, Carlos Alberto. Teoria da imprevisão: sentido atual. Revista dos Tribunais, São Paulo, v. 679, p. 18-29, maio 1992.

40 "Nos contratos agrícolas de venda para entrega futura, o risco é inerente ao negócio. Nele não se cogita em imprevisão" (STF, Terceira Turma. AgRg no REsp no 884.066-GO. Rel. Min. Humberto Gomes de Barros, j. 6.12.2007).

41 AGUIAR JÚNIOR, Ruy Rosado de. Comentários ao Novo Código Civil: da extinção do contrato. Rio de Janeiro: Forense, 2011. v. VI. t. II. p. 900.

42 “A conversão da moeda em URV de que trata a Lei n. 8.880/94 não se apresenta como extorsiva ou exorbitante a justificar a excepcionalidade da Teoria da Imprevisão" (STJ, Segunda Turma. REsp no 650.613SP. Rel. Min. João Otávio de Noronha, j. 23.10.2007). 
(c) A parte contratada deverá continuar a execução do contrato, apesar das dificuldades. ${ }^{43}$

É claro que o contrato, ainda, deverá ser de execução diferida ou continuada (trato sucessivo), comutativo e oneroso. Assim, a teoria da imprevisão não se aplica, em regra, aos negócios instantâneos ou de execução imediata. Tanto que o fundamento da teoria da imprevisão é a cláusula rebus sic stantibus, que é considerada implícita em qualquer contrato de trato sucessivo.

Partindo dessas premissas, as medidas compensatórias serão fixadas amigável ou judicialmente, a fim de cobrir parte do déficit que o contratado sofreu. 0 "estado de imprevisão", sempre temporário, vai intentar restabelecer o equilíbrio do contrato. Do contrário, as partes deverão partir para a sua rescisão do negócio.

Podemos dizer que, contemporaneamente, a teoria da imprevisão aplica-se com menos frequência, porque parcela significativa de contratos empresariais contém cláusulas de revisão dos preços. Assim, tal teoria ainda se aplica e será bastante útil quando essas cláusulas se revelarem inadequadas ou insuficientes.

Um bom exemplo de mecanismo que evita o uso da teoria da imprevisão é o uso da "cláusula de escala móvel", o qual estabelece uma revisão dos pagamentos, que deverão ser feitos em função das variações do preço de certas mercadorias ou serviços, ou do índice geral do custo de vida ou dos salários. Por meio dessa cláusula, os contratantes, no momento da realização do contrato, fazem uma verdadeira previsão sobre o aumento do preço do produto ou serviço, adotando-se, assim, um índice que estabeleça uma "escala móvel" no valor do preço acordado. ${ }^{44}$

\subsection{Teoria da onerosidade excessiva}

A teoria da onerosidade excessiva possui como antecedente histórico o direito romano antigo, a partir da concepção da laesio enormis. Ela é retomada pelo direito italiano no final do século XIX, a par de o Código Civil italiano de 1896 determinar rigidamente o pacta sun servanda. Naquela época, ocorreu incêndio grave em um imóvel em Messena e Regio Calabrio. Tal teoria foi aplicada, com

43 CE, 5 nov. 1982, Société Propétrol.

44 Com isso, tende-se a evitar toda a sorte de discussão judicial ou administrativa no que se refere ao direito de reequilíbrio econômico-financeiro, porque as partes já têm ciência ( $v . g$. é previsível) como será compensada a futura e eventual onerosidade contratual. 
fundamento na cláusula rebus sic stantibus, para que as pessoas prejudicadas pelo fortuito pudessem receber os seguros. ${ }^{45}$

Com a edição do Código Civil de 1942, tal teoria foi positivada expressamente nos arts. 1.467 e $1.468 .{ }^{46}$ No Brasil, a teoria da onerosidade excessiva foi aplicada primeiro aos contratos públicos que tinham por objeto a construção de obra pública, isto já no ano de $1963 .{ }^{47} \mathrm{Em}$ resumo, podem-se elencar os seguintes elementos dogmáticos à aplicação da teoria: (a) há de se estar diante de um evento extraordinário e posterior à constituição do negócio; (b) tal evento deve ter causado uma onerosidade a uma das partes, sendo que, claro, ela não pode ter sido causada por uma das partes; (c) de outro lado, o mesmo evento deve gerar uma maior vantagem para uma das partes contratantes; (d) o evento a ser considerado e que perturbou o equilíbrio contratual deve ser imprevisivel ou previsivel, mas de consequências imprevisiveis. Isto porque, se uma das partes podia considerar razoavelmente possível de ocorrer no futuro tal situação, deveria ter a considerado quando fez o negócio, cabendo, pois, suportar os ônus desta deficiência na avaliação inicial. ${ }^{48}$

Assim, tendo sido apresentadas as principais teorias que abordam a possibilidade de relativização da "força obrigatória dos contratos", permitindo sua revisão diante de um desequilíbrio superveniente das prestações, passa-se à análise específica da revisão dos contratos conforme a "arquitetura jurídica" fixada pelo Código Civil brasileiro de 2002.

\section{A revisão contratual no Código Civil brasileiro}

Em relação ao capítulo anterior, destaca-se que a teoria da excessiva onerosidade foi acolhida pelo Código Civil brasileiro. A Constituição de 1967 foi a primeira que tratou do desequilíbrio de contratos administrativos: sob a redação da Emenda no 1/69, assegurava, nos contratos de concessão de serviços públicos, a manutenção do equilíbrio econômico e financeiro do pacto, por meio da fixação de tarifas reais, suficientes, inclusive, para a justa remuneração do capital e a expansão dos serviços (art. 167, inc. II).

45 BARLETTA, Fabiana Rodrigues. Apontamentos para um estudo comparado da revisão contratual por excessiva onerosidade nos direitos brasileiro, português e italiano. Revista Trimestral de Direito Civil, Rio de Janeiro, v. 24, p. 247-272, out./dez. 2005.

46 Deve ser observado, por oportuno, que o Código Civil italiano de 1942 exclui a possibilidade de aplicar a teoria da onerosidade excessiva aos contratos aleatórios.

47 MARTINS-COSTA, Judith. Comentários ao Novo Código Civil: do direito das obrigações, do adimplemento e da extinção das obrigações. Rio de Janeiro: Forense, 2003. v. 5. t. I. p. 237.

48 Há quem não diferencie os elementos dogmáticos das teorias apresentadas. Por todos: RODRIGUES JR., Otávio Luiz. Revisão judicial dos contratos. São Paulo: Atlas, 2006. p. 156. 
O último antecedente ao Código Civil (CC) no tema é o Código de Defesa do Consumidor (CDC), Lei o 8.078, de 1990, art. 6으, inc. V, que atribui como garantia ao consumidor a revisão contratual. Foi o primeiro diploma de direito privado a recepcionar uma teoria de revisão contratual em decorrência de desequilíbrio contratual. Cabe destacar, no entanto, que o CDC adotou a teoria da base. ${ }^{49}$ Note-se também que não há menção expressa à ideia de imprevisibilidade, apenas a de desequilíbrio contratual, em especial, no art. 6으, inc. V.50

49 Na lição de Cláudia Lima Marques, o Código de Defesa do Consumidor inova em prol da proteção do consumidor, ao alterar o espaço da autonomia da vontade, a fim de equilibrar o contrato. Como exemplo dos mecanismos protetivos, está a cláusula art. 6ำ V, do CDC, que prevê a possibilidade de o juiz modificar a cláusula que estabeleça prestações desproporcionais na superveniência de fato que a torne abusiva. $\mathrm{Na}$ consideração da autora, "o art. 6으, V, do CDC abre uma exceção no sistema da nulidade absoluta das cláusulas, permitindo que o juiz revise ou 'modifique', a pedido do consumidor, as 'cláusulas contratuais que estabeleçam prestações desproporcionais' ou que sejam 'excessivamente onerosas' para ele em razão de fatos supervenientes. [...] Neste sentido, a sanção de nulidade absoluta não seria apta a preencher sua função, mas era necessário autorizar o juiz a agir de forma excepcional, revisando as cláusulas do contrato referentes ao preço para reencontrar o equilíbrio perdido com a atual excessiva onerosidade. Prevê ainda o inciso $\mathrm{V}$ do art. 6 do CDC a possibilidade da revisão judicial da cláusula de preço, que era equitativa quando do fechamento do contrato, mas que em razão de fatos supervenientes tornou-se excessivamente onerosa para o consumidor. A onerosidade excessiva e superveniente que permite o recurso a esta revisão judicial é unilateral, pois o art. 6ㅇ do CDC institui direitos básicos apenas para o consumidor. A norma do art. 6ำ do CDC avança ao não exigir que o fato superveniente seja imprevisível ou irresistível, apenas exige a quebra da base objetiva do negócio, a quebra de seu equilíbrio intrínseco, a destruição da relação de equivalência entre prestações, o desaparecimento do fim essencial do contrato. Em outras palavras, o elemento autorizador da ação modificadora do Judiciário é o resultado objetivo da engenharia contratual, que agora apresenta a mencionada onerosidade excessiva para o consumidor, resultado de simples fato superveniente, fato que não necessita ser extraordinário, irresistível, fato que podia ser previsto e não foi" (MARQUES, Claudia Lima. Contratos no Código de Defesa do Consumidor. o novo regime das relações. 9. ed. São Paulo: Revista dos Tribunais, 2019. Disponível em: https:// proview.thomsonreuters.com/launchapp/title/rt/monografias/100078314/v9. Acesso em: 18 jul. 2020 , item 1.2). Igualmente, consultar: “5. A teoria da base objetiva, que teria sido introduzida em nosso ordenamento pelo art. 6ำ, inciso V, do Código de Defesa do Consumidor - CDC, difere da teoria da imprevisão por prescindir da previsibilidade de fato que determine oneração excessiva de um dos contratantes. Tem por pressuposto a premissa de que a celebração de um contrato ocorre mediante consideração de determinadas circunstâncias, as quais, se modificadas no curso da relação contratual, determinam, por sua vez, consequências diversas daquelas inicialmente estabelecidas, com repercussão direta no equilíbrio das obrigações pactuadas. Nesse contexto, a intervenção judicial se daria nos casos em que o contrato fosse atingido por fatos que comprometessem as circunstâncias intrínsecas à formulação do vínculo contratual, ou seja, sua base objetiva. 6 . Em que pese sua relevante inovação, tal teoria, ao dispensar, em especial, o requisito de imprevisibilidade, foi acolhida em nosso ordenamento apenas para as relações de consumo, que demandam especial proteção. Não se admite a aplicação da teoria do diálogo das fontes para estender a todo direito das obrigações regra incidente apenas no microssistema do direito do consumidor, mormente com a finalidade de conferir amparo à revisão de contrato livremente pactuado com observância da cotação de moeda estrangeira. 7. Recurso especial não provido" (STJ, 3ạ Turma. REsp no 1.321.614/SP. Rel. Min. Paulo de Tarso Sanseverino, Rel. p/ Acórdão Min. Ricardo Villas Bôas Cueva, j. 16.12.2014). Por fim: MARQUES, Claudia Lima; BENJAMIN, Antonio Herman V.; MIRAGEM, Bruno. Comentários ao Código de Defesa do Consumidor. 6. ed. São Paulo: Revista dos Tribunais, 2019. Disponível em: https://proview.thomsonreuters.com/launchapp/title/rt/codigos/72654266/v6. Acesso em: 18 jul. 2020, comentários ao artigo 6ำ, V).

50 CDC, art. 6으, inc. V: “Art. 6오 São direitos básicos do consumidor: [...] V - a modificação das cláusulas contratuais que estabeleçam prestações desproporcionais ou sua revisão em razão de fatos supervenientes que as tornem excessivamente onerosas; [...]". 
Apenas no Código Civil de 2002 é que há regulamentação da matéria de revisão contratual, cujo tratamento é feito nos arts. 317, 478, 479 e 480 da referida legislação. ${ }^{51}$ Ressalta-se que os três últimos dispositivos são reprodução do Código Civil italiano, de 1942, e, em razão disso, adotou-se a onerosidade excessiva. ${ }^{52}$ Vale dizer, nesse aspecto, que o tratamento jurídico-positivo da revisão contratual é um pouco "conturbado", seja porque a matéria era genericamente prevista no direito civil (pela dificuldade de introduzir a matéria), seja porque há divergência doutrinária sobre os requisitos e sobre a consequência na ocorrência. De qualquer sorte, prevalece no Código Civil a teoria da onerosidade excessiva. ${ }^{53}$ Há quem critique essa opção da redação do art. 478 , pois o foco recai no devedor, e não nas circunstâncias que levam à alteração do contrato. ${ }^{54}$

\subsection{0 art. 317 e 0 art. 478 do CC}

Os arts. 478 e 317 possuem configurações diferentes, ${ }^{55}$ pois a interpretação literal de cada qual se mostra conflitante. 0 art. 317 está situado no âmbito do pagamento e tutela a situação em que, por motivos imprevisíveis, ocorre desproporção entre o valor da prestação devida e aquela a ser efetivada no momento do pagamento. Esta conjuntura permite ao juiz corrigir a desproporção, de modo a assegurar o valor real da prestação. 0 objetivo é readequar a equação econômica do contrato, e não a de extinguir o contrato.

De fato, faz-se necessária uma comparação entre os arts. 317 e 480 do CC. 0 art. 317 está na parte das obrigações e prevê a revisão da prestação que estiver em desequilíbrio no momento da sua execução. Cabe aqui destacar que

51 De acordo com o Código Civil: “Art. 317. Quando, por motivos imprevisíveis, sobrevier desproporção manifesta entre o valor da prestação devida e o do momento de sua execução, poderá o juiz corrigi-lo, a pedido da parte, de modo que assegure, quanto possível, o valor real da prestação. [...] Art. 478. Nos contratos de execução continuada ou diferida, se a prestação de uma das partes se tornar excessivamente onerosa, com extrema vantagem para a outra, em virtude de acontecimentos extraordinários e imprevisíveis, poderá o devedor pedir a resolução do contrato. Os efeitos da sentença que a decretar retroagirão à data da citação. Art. 479. A resolução poderá ser evitada, oferecendo-se o réu a modificar equitativamente as condições do contrato. [...] Art. 480. Se no contrato as obrigações couberem a apenas uma das partes, poderá ela pleitear que a sua prestação seja reduzida, ou alterado o modo de executá-la, a fim de evitar a onerosidade excessiva".

52 Tal teoria foi abordada no item 1.3 deste trabalho.

53 MARTINS-COSTA, Judith. Comentários ao Novo Código Civil: do direito das obrigações, do adimplemento e da extinção das obrigações. Rio de Janeiro: Forense, 2003. v. 5. t. I; AGUIAR JÚNIOR, Ruy Rosado de. Comentários ao Novo Código Civil: da extinção do contrato. Rio de Janeiro: Forense, 2011. v. VI. t. II.

54 BORGES, Nelson. A teoria da imprevisão no direito português. Genesis: Revista de Direito Processual Civil, Curitiba, n. 13, p. 560-581, 1999.

55 GRAMSTRUP; Erik Frederico. Contratos relacionais. In: LOTUFO, Renan; NANNI, Giovanni Etore (Coord.). Teoria geral dos contratos. São Paulo: Atlas, 2011. 
o Anteprojeto do Código Civil, aprovado em 2002, possui sua gênese ainda no fim da década de 1960, e que esse mesmo Anteprojeto tinha muitos pontos que não foram incorporados à realidade do $\mathrm{CC} / 2002$ na sua integralidade. Quando da primeira versão do Anteprojeto de Código, em 1970, estava-se diante de um surto inflacionário. Logo, é prevista medida corretiva neste sentido, ou seja, com isto o juiz poderia corrigir (readequar) a prestação, para promover a revisão da correção monetária. Contudo, a legislação brasileira foi aprimorada, ainda nos anos 1980, permitindo a incidência da correção monetária automática, o que tornou desnecessária a aplicação do disposto no art. 317, tal qual previsto nos anos 1970. Então, o dispositivo passou por uma adaptação. Isso acabou criando certo antagonismo dentro do Código, porque há dois dispositivos que disciplinam a matéria, mas têm propósitos distintos.

De um lado, há quem tente expandir o art. 317, por ser menos rigoroso, e por ser favorável ao pacta sunt servanda. Por outro lado, pode-se compreender que o mesmo dispositivo é bastante específico em relação ao ajuste/revisão da prestação pecuniária. A sua função, tal como a evolução histórica demonstra, serve e servia para revisão de dívidas pecuniárias, mas não para revisão/reequilíbrio do contrato como um todo.

A rigor, o art. 317 permitiria ao juiz uma intervenção direta no programa contratual, enquanto o art. 478 autorizaria apenas a resolução do contrato. Orlando Gomes $^{56}$ entende que a onerosidade excessiva também concede poderes de revisão do contrato pelo juiz, pelo princípio da conservação dos contratos. ${ }^{57}$ Gustavo Tepedino, ${ }^{58}$ por sua vez, entende que o art. 478 é que deveria ser estendido, para, com base na função social do contrato e da boa-fé, permitir primeiro a revisão - e não a mera resolução. Junqueira de Azevedo ${ }^{59}$ defende que o art. 317 apenas seria aplicável às dívidas de valor (aquelas nas quais o quantum debeatur precisa ser liquidado). Luís Gastão Paes Leães também é expresso ao referir que o art. 317 não deve ser confundido com o 478, pois "[...] a disciplina introduzida pelo art. 317

56 GOMES, Orlando. Contratos. Rio de Janeiro: Forense, 2008. v. 3. p. 231-232.

57 Para os fins de análise neste artigo, adota-se a conceituação de princípio de Humberto Ávila: “Quanto aos princípios, Humberto Ávila perfaz sua conceituação a partir de um critério finalístico: são normas imediatamente finalísticas, primariamente prospectivas e com pretensão de complementaridade e de parcialidade. Sua aplicabilidade reclama uma avaliação da correlação entre o estado de coisas a ser promovido e os efeitos decorrentes da conduta havida como necessária à sua promoção. Eles impõem um dever para que se consiga chegar a um estado de coisas ou, inversamente, instituem o dever de efetivação de um estado de coisas pela adoção de comportamento a ele necessário" (ÁVILA, Humberto. Teoria dos princípios - Da definição à aplicação dos princípios jurídicos. São Paulo: Malheiros, 2004. p. 70-72).

58 TEPEDINO, Gustavo et al. Código Civil interpretado conforme a Constituição da República. Rio de Janeiro: Renovar, 2006.

59 AZEVEDO, Antônio Junqueira de. Relatório brasileiro sobre a revisão contratual apresentado para as Jornadas Brasileiras da Associação Henri Capitant. In: AZEVEDO, Antônio Junqueira de. Novos estudos e pareceres de direito privado. São Paulo: Saraiva, 2004. p. 187. 
da nova lei civil não pode ser associada à regulação da resolução contratual por onerosidade excessiva, que mereceu tratamento específico e exaustivo no novo Código, nos seus arts. 478 a $480 " .60$

Dessa forma, o art. 317 seria aplicável apenas às dívidas em dinheiro, que “[...] em decorrência de motivos imprevisíveis (v.g., hiperinflação, maxidesvalorização cambial, deflação exagerada, etc) tenham seu valor real alterado entre o momento da celebração do negócio e o de sua execução". ${ }^{61}$ Assim, no entender dos autores deste artigo, o art. 317 é aplicável apenas à correção das prestações pecuniárias, pela sua própria redação e pela seção do Código onde está inserido (v.g. art. 315 - dívidas em dinheiro). Assim, feitas as distinções entre os dispositivos 317 e 478 e seguintes do Código Civil, passa-se a tratar dos requisitos necessários à revisão contratual, de acordo com o art. 478.

\subsection{Requisitos dispostos no art. $\mathbf{4 7 8}$ do CC}

De modo bastante objetivo, em relação aos requisitos dispostos no art. 478 do Código Civil, há que se verificar: (a) se a execução do contrato é continuada ou diferida; (b) a superveniência de fato imprevisível e extraordinário; (c) a ocorrência de ônus excessivo para uma das partes; e (d) a existência de extrema vantagem para a contraparte.

A ocorrência desses requisitos deve ser concomitante. Ademais, apesar da inspiração italiana do Código Civil brasileiro, há que se destacar que o art. 478 do CC é mais restrito que o art. 1.467 do CC italiano, ao exigir que a contraparte seja beneficiada com extrema vantagem.

No que tange aos contratos que se submetem à revisão, em primeiro lugar, deve ser destacado que tal instituto é focado aos contratos em execução continuada ou diferida. Os contratos de execução continuada são aqueles que demoram certo tempo, em que as obrigações das partes contratantes não se implementam de modo imediato. Importam na realização de prestações periódicas e contínuas, a exemplo da locação. Aqui o requisito é aplicado de forma ampla, ou seja, incide em qualquer caso em que a execução das prestações se protraia no tempo, salvo se ocorrido por fato imputável e culposo de alguma das partes.

Já nos contratos de "execução imediata", não há um lapso temporal significativo entre a assinatura e a execução, como se percebe, por exemplo, na compra

60 LEÃES, Luís Gastão Paes de Barros. Resolução por onerosidade excessiva. Revista de Direito Mercantil, Industrial, Econômico e Financeiro, São Paulo, v. 54, n. 140, p. 23-37, 2005. p. 28.

61 YAMASHITA, Hugo Tubone. Contratos interempresariais: alteração superveniente das circunstâncias fáticas e revisão contratual. Curitiba: Juruá, 2015. p. 155. 
e venda à vista. Pode ser que haja garantia pós-contratual (como a evicção), mas não é ela decorrente do lapso temporal, nem se trata de execução posterior. Vale dizer que, nesta modalidade, as eventuais circunstâncias que afetem o contrato não decorrem do tempo. Então, aqui, em caso de prestação desequilibrada, estarse-á diante de caso de nulidade, de inadimplemento ou de obrigação pós-contrato.

Ressalta-se que diferimento é gênero, enquanto a execução continuada é espécie. É preciso, então, diferenciar as modalidades de contratos diferidos, pois as consequências serão diversas. Basicamente, há três modalidades: (a) contrato a termo ou sob condição. Exemplo: a compra e venda de automóvel, com a entrega do bem e pagamento sessenta dias depois de firmado o acordo. Nesta hipótese, cabe apenas aguardar o lapso mencionado; (b) contrato diferido, mas em que já há execução: (b.1) os atos são parcelas de uma única prestação. Exemplo: doze parcelas da prestação de pagar o preço, e o adimplemento fica condicionado ao pagamento das mencionadas doze prestações, sob pena de retroação (efeitos ex tunc) à data da realização do contrato; (b.2) contrato de trato sucessivo, o qual remunera integralmente cada parte, como ocorre no contrato de locação. Nesta hipótese, se sobrevier uma necessidade de revisão, os efeitos não serão retroativos, mas ex nunc. ${ }^{62}$

Compreendidos quais contratos podem ser submetidos à revisão contratual, deve-se examinar quais circunstâncias supervenientes abalam o contrato a ponto de ensejar a revisão. 0 art. 478 determina que a superveniência deve ser de fato imprevisível e extraordinária, cumulativamente. ${ }^{63}$

Contudo, apesar da previsão feita no art. 478 sobre a necessidade de se cumular fato imprevisível com o extraordinário, acolhida pela compreensão da doutrina, que se posiciona no mesmo sentido, a jurisprudência vem aplicando apenas um dos critérios, alternativamente. ${ }^{64}$ Neste aspecto, Hugo Tubone Yamashita propõe que a imprevisibilidade do evento deve ser examinada

[...] de acordo com o grau de probabilidade de que determinado acontecimento venha a se concretizar, causando impactos ao acordo negociado entre os contratantes. Quanto menor a probabilidade de que

62 Em termos de contratos empresariais diferidos, a teoria da onerosidade excessiva é de larga aplicação, inclusive como uma forma de estímulo ao mercado e preservação da ordem econômica, na dimensão política da sociedade (cf. FORGIONI, Paula. Teoria geral dos contratos empresariais. São Paulo: Revista dos Tribunais, 2009. p. 194).

63 Na lição de Orlando Gomes, fato imprevisível pode ser assim definido: “Necessário ainda que a alteração imprevisível do estado de fato determine a dificuldade de o contratante cumprir a obrigação, por se ter tornado excessivamente onerosa a prestação. A modificação quantitativa da prestação há de ser tão vultuosa que, para satisfazê-la, o devedor se sacrificaria economicamente" (GOMES, Orlando. Contratos. Rio de Janeiro: Forense, 2008. v. 3. p. 41).

64 STJ, 4a Turma. REsp no 936.741-GO. Rel. Min. Antônio Carlos Ferreira, j. 3.11.2011. 
determinado acontecimento ocorra, maiores são as chances de que seja considerado imprevisível. ${ }^{65}$

Também se deve realizar o exame das condições pessoais dos contratantes, sobre seus conhecimentos prévios - que determinam a capacidade de analisar e antever eventos e consequências.

Na mesma linha de pensamento, Ruy Rosado ${ }^{66}$ entende que as circunstâncias pessoais dos contratantes devem ser levadas em conta. Ademais, na visão do autor, a imprevisibilidade deve acompanhar a ideia de probabilidade. Tal circunstância, aliás, não pode ser absoluta, porque afastaria a possibilidade de revisão, ou seja, ela precisa estar ligada na ideia de razoabilidade, considerando o meio, o local, as circunstâncias do negócio etc. Desta forma, afasta-se daquilo que não for razoável. Ademais, Nelson Borges ${ }^{67}$ destaca que a imprevisibilidade pode resultar em dois aspectos: (a) o próprio evento; (b) os efeitos do evento, cuja divisão facilita o exame das circunstâncias e as conclusões.

Em relação à condição de imprevisibilidade, Venosa ressalta que as condições subjetivas de cada contratante (v.g. divórcio, desemprego etc.) não devem ser suficientes para ensejar a revisão contratual, mas sim que o evento deve ser de tal sorte grave, a ponto de atingir um segmento da sociedade. ${ }^{68}$ No que tange à interpretação dos contratos empresariais, destaca Joaquim de Souza Ribeiro que “[...] deve prevalecer a autodeterminação e autorresponsabilidade do contratante [...]", 69 justamente pela qualidade de profissional e de acesso à informação.

Além disso, conforme já foi consolidado pela III Jornada de Direito Civil no Enunciado no 175: "A menção à imprevisibilidade e à extraordinariedade, insertas no art. 478 do Código Civil, deve ser interpretada não somente em relação ao fato que gere o desequilíbrio, mas também em relação às consequências que ele produz".

Já no que tange ao "fato extraordinário", cabe referir que este elemento dogmático da teoria deve ser referir a acontecimento fora da ordem natural do contrato, saindo da álea do negócio, ou seja, ser de caráter excepcional. ${ }^{70}$ Tal como em Venosa, ${ }^{71}$ a imprevisibilidade e extraordinariedade devem atingir parcela

65 YAMASHITA, Hugo Tubone. Contratos interempresariais: alteração superveniente das circunstâncias fáticas e revisão contratual. Curitiba: Juruá, 2015. p. 139

66 AGUIAR JÚNIOR, Ruy Rosado de. Extinção dos contratos por incumprimento do devedor. Rio de Janeiro: Aide, 1991.

67 BORGES, Nelson. A teoria da imprevisão no direito português. Genesis: Revista de Direito Processual Civil, Curitiba, n. 13, p. 560-581, 1999.

68 VENOSA, Sílvio de Salvo. Direito civil: teoria geral das obrigações e teoria geral dos contratos. 10. ed. São Paulo: Atlas, 2010.

69 RIBEIRO, Joaquim de Souza. O problema do contrato. Coimbra: Almedina, 1999. p. 288-293.

70 TARTUCE, Flávio. Manual de direito civil. São Paulo: Método, 2016. p. 595.

71 Nesse sentido, consultar o julgado: TJSP, 36ª Câmara de Direito Privado. Apelação no 992.09.032133-1, Acórdão no 423.191 - Santos. Rel. Des. Romeu Ricupero, j. 8.1.2010. DJESP, 12 fev. 2010. 
da sociedade para serem consideradas relevantes em termos de reconhecimento da revisão contratual. Em síntese: quando configurado o fato imprevisível e extraordinário que venha a gerar uma excessiva onerosidade para um dos lados ${ }^{72}$ e excessiva vantagem para a contraparte, pode ser aplicado o disposto no art. 478 do CC. E, neste caso, há que se verificar quais são os tipos de consequência aos contratos. Por exemplo, não se enquadraria nesta hipótese a desvalorização cambial, pois ela causaria prejuízo a uma das partes, mas não necessariamente traria vantagem à outra parte.

Quanto a esse último aspecto, Laura Frantz ${ }^{73}$ entende que a ideia de vantagem não se liga a uma perspectiva individual, mas deve estar relacionada a uma perspectiva de mercado. Em outras palavras, para verificar se a vantagem é ou não individual, deve se questionar se o contrato, caso exposto às situações de mercado, teria as mesmas consequências, ou se as vantagens ou desvantagens dele advindas são decorrentes da excessiva onerosidade superveniente.

Ademais, no que diz respeito à extrema vantagem para a contraparte, certos acontecimentos como guerras e planos de intervenção econômica nem sempre criam vantagem para a parte não prejudicada. No entanto, deve se ponderar que esse é um requisito que limita bastante as hipóteses de revisão contratual, pois, além de a outra parte ter restado onerada, o desequilíbrio deve beneficiar em demasia a outra parte. Por exemplo, às vezes se configura um excessivo desequilíbrio, mas que não resulta em um ganho maior que antes.

Para de certa forma "corrigir" esta distorção, a IV Jornada de Direito Civil tratou deste tema, no Enunciado no 365, da seguinte forma: "A extrema vantagem do art. 478 deve ser interpretada como elemento acidental da alteração das circunstâncias, que comporta a incidência da resolução ou revisão do negócio por onerosidade excessiva, independentemente de sua demonstração plena". Logo, amenizou-se a estrutura jurídico-positiva do art. 478 do $\mathrm{CC}$, no que se refere à necessidade da presença da "extrema vantagem" para uma das partes contratantes.

Na lição de Fernando Noronha, ${ }^{74}$ todo contrato pressupõe um conjunto de circunstâncias objetivas imprescindíveis à economia do negócio. Quando as circunstâncias se alteram, é absolutamente justificada a revisão contratual, ou, quando não for possível, a própria resolução do ajuste.

72 A "onerosidade" mencionada refere-se a uma "dificuldade" maior de uma das partes contratantes, e não "impossibilidade" de contratar.

73 FRANTZ, Laura Coradini. Revisão dos contratos: elementos para sua construção dogmática. São Paulo: Saraiva, 2007.

74 NORONHA, Fernando. O direito dos contratos e seus princípios fundamentais: autonomia privada, boa-fé, justiça contratual. São Paulo: Saraiva, 1994 


\subsection{Requisitos implícitos do art. 478 do CC}

Cabe destacar que, para além dos requisitos expressos do art. 478, há que se considerar os requisitos implícitos, conforme a seguir examinados. Em primeiro lugar, a aplicação da revisão contratual disposta na referida regra aplica-se aos contratos onerosos. E, de outro lado, não incide aos contratos aleatórios, cujo risco é o cerne do negócio. Estes últimos ajustes têm uma zona de risco em caso de não cumprimento que não comporta revisão. A grande diferença dos contratos comutativos e dos aleatórios está justamente na ideia de que, nestes últimos, a prestação não sobrevenha, como é percebido nos contratos de seguro (típicos contratos aleatórios). No caso, tradicionalmente não se espera acionar o ajustado no contrato. E a mesma ideia pode ser transportada em contratos de risco como o de aposta. No mesmo sentido, encaminha-se o Enunciado no 440 da V Jornada de Direito Civil: "É possível a revisão ou resolução por excessiva onerosidade em contratos aleatórios, desde que o evento superveniente, extraordinário e imprevisível não se relacione com a álea assumida no contrato".

Ademais, a respeito da imputabilidade da mora, ela não pode ser imposta a quem alega a onerosidade excessiva (ninguém pode se locupletar da sua própria torpeza). Luís Gastão Leães ${ }^{75}$ expõe que "[...] não se admite a que o requerimento judicial de resolução seja formulado antes do evento inesperado causador de onerosidade, nem depois de o devedor ter incorrido em mora". Yamashita ${ }^{76}$ demonstra que parte da doutrina, com fulcro no art. 399, entende que o devedor em mora não poderia se socorrer de resolução do contrato. No entanto, José de Oliveira Ascensão ${ }^{77}$ pensa diferente, porque demonstra que o devedor em mora poderia invocar a onerosidade excessiva, desde que demonstrado que a circunstância ocorreria de qualquer modo, com ou sem mora.

Em relação à alea extracontratual, os riscos da superveniência não podem ter sido assumidos pelas partes. Por exemplo, se o risco for assumido expressamente em uma cláusula contratual, ainda que o fato seja imprevisível e extraordinário, ele está inserto na lógica contratual, pela distribuição dos riscos. E a jurisprudência, a respeito do tema, empreendeu entendimento no mesmo sentido. Trata-se do "caso da soja verde", em Goiás. Na prática, os agricultores pré-contratavam a venda da safra futura, preestabelecendo o valor da venda dessa

5 LEÃES, Luís Gastão Paes de Barros. Resolução por onerosidade excessiva. Revista de Direito Mercantil, Industrial, Econômico e Financeiro, São Paulo, v. 54, n. 140, p. 23-37, 2005. p. 34.

76 YAMASHITA, Hugo Tubone. Contratos interempresariais: alteração superveniente das circunstâncias fáticas e revisão contratual. Curitiba: Juruá, 2015. p. 147.

77 ASCENSÃO, José de Oliveira. Alteração das circunstâncias e justiça contratual no Novo Código Civil. Revista Trimestral de Direito Civil, ano 7, v. 25, jan./mar. 2006. 
safra. No entanto, o preço da soja internacional disparou, aumentando consideravelmente. Com base nisto, tais agricultores invocaram um precedente da Corte sobre leasing para pedir revisão do contrato. Contudo, no caso do contrato de soja, há uma clara distribuição do risco na contratação, pois se afasta a álea da oscilação do preço, e se escolhe a segurança de ter um comprador, o que não ensejaria revisão pretendida. ${ }^{78}$

Ainda, no tema dos elementos implícitos da revisão, há que se considerar os gatilhos revisionais que promovem a revisão contratual. ${ }^{79}$ Como dissemos, o contrato tem como seu maior desafio o tempo. Para garantir o equilíbrio das obrigações, há “fórmulas de adaptação do contrato", como as cláusulas de adaptação automática (exemplo: o índice altera, afeta o preço e é reajustado), ${ }^{80}$ cuja atuação ocorre quando o evento previsto se realiza. E há "cláusulas de adaptação semiautomática", quando dependem de que uma das partes escolha ou crie o gatilho (exemplo: a chamada "cláusula de cliente mais favorecido", que ocorre quando uma disposição negocial estabelece algo do tipo: "se forem feitas novas contratações, deve-se oferecer antes ao primeiro cliente" - logo, é disposição que depende da vontade das partes). Em síntese: não se discute o direito de fazer a revisão, mas o gatilho revisional depende de acionamento por um dos sujeitos contratantes.

E há as "cláusulas não automáticas" que impõem a obrigação de renegociação do contrato. Em relação a elas, destaca-se a cláusula de hardhip. Tal disposição negocial impõe um dever de renegociação do contrato se a contínua execução da prestação de uma das partes se tornou excessivamente onerosa devido a um evento imprevisto e fora do controle da parte. O fundamento teórico da cláusula de hardship reside na autonomia privada e na manutenção da base econômica do contrato. O que legitima sua invocação seria o prejuízo de um dos contratantes, causado por evento imprevisível e exterior à vontade das partes e que alterasse

8 STJ, 3a Turma. REsp no 803.481-GO. Rel. Min. Nancy Andrighi, j. 28.6.2007.

79 MARTINS-COSTA, Judith. Comentários ao Código Civil: do direito das obrigações. Do adimplemento e da extinção das obrigações (arts. 304 a 388). Rio de Janeiro: Forense, 2005. v. V. t. I. p. 262; BILLIAU, Marc; GHESTIN, Jacques. Le prix dans les contrats de longue durée. Paris: LGDJ, 1990. p. 137.

80 Inclusive, o STJ recentemente manteve decisão que considerou válida a cláusula de renovação automática, conforme se infere dos seguintes trechos do acórdão: "De outra banda, conforme sustentado na sentença, 'as cláusulas apontadas pela autora como abusivas visaram, tão somente, oferecer segurança contratual para ambos os contratantes, no tocante tanto à duração do contrato de fornecimento de gases quanto das quantidades mínimas a serem disponibilidades' [...]. Na verdade, verifica-se que as cláusulas pactuadas entre as partes que estabeleceram prazo de validade do contrato, renovação automática caso nenhuma das partes tenha entendido pela sua descontinuidade - e fornecimento mensal mínimo de gases, embora não tenham sido totalmente favoráveis à parte autora, acabaram por proporcionar à parte autora um preço mais vantajoso na aquisição dos gases e, por via de consequência, um preço final mais vantajoso e um lucro maior na comercialização dos extintores, inexistindo, assim, qualquer abusividade nas cláusulas existentes no contrato havido entre as partes" (STJ. AREsp no 649.641-RS. Rel. Min. Maria Isabel Gallotti. DJ, 29 maio 2015). 
a "economicidade" do contrato. ${ }^{81}$ Esclarecendo essa peculiaridade, Luiz Olavo Baptista afirma: "As circunstâncias, imprevisíveis sempre, e exteriores à vontade das partes, ao contrário do que ocorre com a força maior, não se devem às forças da natureza ou a fatos de terceiros, mas a movimentos do ambiente do contrato, especialmente os da economia". 82

Por outro lado, as cláusulas de revisão do contrato são geralmente estipuladas em função de uma das partes, e se restringem a um elemento do contrato (o preço). Já as de indexação se limitam à manutenção do valor, operando de maneira automática e cobrindo somente os riscos monetários. ${ }^{83}$ Assim, verificados os elementos, as causas e as consequências da onerosidade excessiva para os contratos empresariais, cabe agora examinar se a onerosidade excessiva constitui um princípio geral do direito.

\section{A onerosidade excessiva como um princípio geral do direito}

De um lado, importante notar esta ideia de "princípio geral do equilíbrio contratual", como uma categoria jurídica que geraria efeitos a qualquer ajuste, presentes os seus elementos nucelares, não possui previsão normativa, como assim feito no direito dos contratos administrativos. Neste último âmbito, a própria Constituição da República Federativa do Brasil de 1988, no inc. XXI do art. 37, determinou expressamente que tais ajustes devam guardar hígido o "equilíbrio econômico-financeiro". ${ }^{84}$ Contudo, no âmbito privado, não existem expressadas no ordenamento jurídico-positivo normas de introdução à equidade dos contratos.

Logo, resta pensar se existe ou não um "princípio geral" neste sentido, ainda que de modo implícito. Em outros termos, diante de um desequilíbrio contratual, e presentes certos requisitos, haveria um direito a uma das partes contratantes de pleitear, em relação a outra, a revisão do negócio?

81 GOMES, Orlando. A “hardship clause” no contrato de empreitada. In: GOMES, Orlando. Novíssimas questões de direito civil. São Paulo: Saraiva, 1984. p. 187.

82 BAPTISTA, Luiz Olavo. O risco nas transações internacionais: problemática jurídica e instrumentos (de defesa). Revista de Direito Público, São Paulo, n. 66, abr./jun. 1983. p. 270.

83 OPPETIT, Bruno, L'adaptation des contrats internationaux aux changements de circonstances: la clause de hardship. Journal du Droit International, n. 4, out./dez. 1974. p. 794-795.

84 Sendo que tal dispositivo é complementado, em nível infraconstitucional, pelo art. 65, inc. II, alínea "d", da Lei $n$ ㅇ 8.666/93: “Os contratos regidos por esta Lei poderão ser alterados, com as devidas justificativas, nos seguintes casos: [...] II - por acordo das partes: [...] d) para restabelecer a relação que as partes pactuaram inicialmente entre os encargos do contratado e a retribuição da administração para a justa remuneração da obra, serviço ou fornecimento, objetivando a manutenção do equilíbrio econômico-financeiro inicial do contrato, na hipótese de sobrevirem fatos imprevisíveis, ou previsíveis porém de consequências incalculáveis, retardadores ou impeditivos da execução do ajustado, ou, ainda, em caso de força maior, caso fortuito ou fato do príncipe, configurando álea econômica extraordinária e extracontratual”. 
Para responder a esta pergunta, poder-se-ia compreender, quiçá, que a figura da boa-fé objetiva (arts. 113, 187 e 422 do CC) poderia ser fundamento bastante para se fixar uma "cláusula geral de equilíbrio". No caso, pensa-se que este entendimento não se sustenta, porque o instituto da boa-fé não cria obrigações novas. Ele apenas incrementa deveres que já existiam em relação às obrigações fixadas. A boa-fé objetiva até pode explicar a proteção ao equilíbrio, mas não pode servir como uma base jurídica ao seu nascedouro. ${ }^{85}$

Antes de tudo, deve-se perceber, com clareza, que a formação do sinalagma negocial gera a mencionada correspectividade de prestações entre as partes negociantes. Portanto, a causa do contrato mostra-se essencial neste aspecto, uma vez que se forma uma promessa de se deslocar prestações economicamente apreciáveis, as quais operam de modo recíproco. Para tanto, deve-se reconduzir a pesquisa sobre o tema, perguntando-se em qual momento há a formação do equilíbrio contratual?

Dito isto, não se está a falar em "justiça contratual", mas, sim, em "justiça daquilo que as partes contrataram". Note bem que a relação contratual não pressupõe identidade de prestações, mas, sim, um equilíbrio negociado, o que não necessariamente revela "justiça entre as partes". Veja que é plenamente aceitável pelo ordenamento civil pátrio que os sujeitos contratantes negociem prestações desproporcionais. Assim que outra conclusão é aqui firmada: o equilíbrio contratual não é compreendido objetivamente, mas, sim, subjetivamente, porque são as partes que atribuem um valor de troca às prestações contratuais. ${ }^{86}$

Então, o elemento dogmático nodal a conferir razão à revisão dos contratos é a sua causa sinalagmática. Resta ao jurista saber qual seria o limite aceitável da desproporção, o que, em uma ótica pessoal, será balizado pelo direito positivo, ${ }^{87}$ e, principalmente, pela intenção das partes. ${ }^{88} \mathrm{E}$ este é o ponto-chave da revisão. A rigor, a ideia de "conservação dos contratos", prevista no art. 170 do CC, 89 justifica também o reequilíbrio, o que ratifica a compreensão de que a causa dos contratos, combinada com o fator subjetivo negocial (intenção das partes), são elementos dogmáticos nucleares à espécie.

85 Sobre o tema da boa-fé nos contratos de direito privado, ressaltam-se as obras de: NORONHA, Fernando. O direito dos contratos e seus princípios fundamentais: autonomia privada, boa-fé, justiça contratual. São Paulo: Saraiva, 1994; e MARTINS-COSTA, Judith. A boa-fé no direito privado. Critérios para a sua aplicação. São Paulo: Marcial Pons, 2015.

86 É claro que estamos a discorrer acerca do equilíbrio de contratos empresariais, já que, em outros campos do direito privado, como o consumerista, a desproporção poderia também ser avaliada de modo objetivo, a fim de proteger o consumidor, presumidamente vulnerável nesta relação.

87 Por exemplo: regras de proibição de usura, de tabelamento de prazo de revisão etc.

88 Ganha relevo, aqui, o que dispõe o art. 112 do CC: “Nas declarações de vontade se atenderá mais à intenção nelas consubstanciada do que ao sentido literal da linguagem".

89 CC, art. 170: "Se, porém, o negócio jurídico nulo contiver os requisitos de outro, subsistirá este quando o fim a que visavam as partes permitir supor que o teriam querido, se houvessem previsto a nulidade". 
Significa dizer, em outros termos, que o equilíbrio contratual, se visto como "princípio geral do direito privado", tem por meta manter o que as partes pretenderam quando da celebração do negócio. E isto revela a necessidade de se perguntar por que se estabeleceu a troca. Se a realidade se modifica no tempo, e o contrato ainda está vigente, deve-se questionar: "a parte onerada ainda continuaria negociando, diante da situação em que se encontra agora?”; ou, de outro modo: "se, à época da celebração do negócio, a parte soubesse dos câmbios que se processaram durante a execução do contrato, teria ainda assim feito o ajuste que se está a questionar?". E tudo isto deve, é claro, ser visto em termos economicamente apreciáveis. Se a resposta a estes questionamentos indica que uma das partes jamais teria feito o negócio ou continuado o contrato, percebemos a presença, no mínimo, do enriquecimento sem causa da outra parte que se beneficia da onerosidade. ${ }^{90}$ Até porque, como se viu logo antes, ${ }^{91}$ o Código Civil fala em "desproporção manifesta" (art. 317), o que dá uma ideia negativa, e não positiva. Esta perspectiva, também como demonstrado, não se repete no art. 478, porque esta regra se pauta na perspectiva de uma "prestação excessivamente onerosa". Assim, o código parte de uma ideia de equidade que se baseia na compreensão de que há impossibilidade de vantagem exagerada de uma das partes, situação que deve se manter durante o contrato.

Vale dizer, assim, que a objetivação do contrato propõe dar menos valor à declaração de vontade, e valorar mais a visão econômico-social do contrato. Repetese, não se pode perder de vista que o contrato é uma operação econômica, ${ }^{92}$ o que reforça a tese exposta.

É claro que não se pode dar guarita à revisão contratual quando, no futuro, era razoável para as partes contratantes prever a justa perda patrimonial, ou seja, o câmbio da realidade era previsível. Então, se era razoável prever uma justa perda patrimonial (v.g., sabia-se que existiria, no futuro, mudança do sinalagma), não há que se dar guarita ao reequilíbrio contratual. E por uma simples razão: o fato que rompe a relação continua no âmbito de previsibilidade das partes desde a gênese do negócio. Logo, em outras palavras, faz parte da causa do contrato.

Assim, o Código Civil não prevê expressamente um "princípio do equilíbrio contratual”. O que existe é uma relação jurídica sinalagmática guiada por um equilíbrio subjetivamente apreciado e que se projeta no contrato. Em outras palavras,

Incidência, aqui, do art. 884 do CC, que trata do enriquecimento sem causa

1 Item 2 - segunda parte deste trabalho.

92 SILVA, Luis Renato Ferreira da. A função social do contrato no Novo Código Civil e sua conexão com a solidariedade social. In: SARLET, Ingo Wolfgang. O Novo Código Civil e a Constituição. Porto Alegre: Livraria do Advogado, 2003. p. 136. 
o "equilíbrio funcional" dos contratos deve ser garantido $-{ }^{93}$ pela intenção comum das partes.

$\mathrm{E}$, de mais a mais, a resolução contratual deve ser a ultima ratio, ou seja, a todo custo deve ser evitada. Antes de se romper com o negócio, impõe-se seja oferecido à outra parte contratante a possibilidade de modificar equitativamente as condições do contrato - tudo de acordo com o que dispõe o art. 479 do CC. Assim, este dispositivo deve ser considerado, porque a base do contrato se assenta, antes de tudo, em uma relação de interesse entre as partes. De qualquer sorte e de outro lado, não se pode impor o reequilíbrio, porque a resolução do negócio pode ser uma boa opção.

\section{Conclusão}

Ao longo do trabalho, examinou-se a relevância do tempo para os contratos empresariais, suas características de indefinição e indeterminação para o cumprimento das obrigações. No decurso do tempo, a realidade das partes pode divergir daquela originalmente avençada, imputando à contraparte o ônus de um negócio extremamente difícil de cumprir, caracterizado pela onerosidade excessiva superveniente.

Na busca pela compreensão dos meios de se retomar o equilíbrio de outrora, examinaram-se as teorias "clássicas" quanto ao tema, a saber: a teoria da base do negócio jurídico, a teoria da imprevisão e a teoria da onerosidade excessiva. Foram examinadas, aqui, pela sua relevância internacional e pela sua influência no cenário brasileiro. A seguir, foi exposta a perspectiva nacional sobre a revisão/ resolução de contratos, e o tratamento do tema formulado no Código Civil, especificamente nos arts. 317 e 478 , seja no que se refere aos requisitos explícitos, seja no que tange aos requisitos implícitos.

Em seguida, examinou-se se a onerosidade excessiva pode ser considerada um "princípio geral do direito", ao que se concluiu não ser possível. O Código Civil não faz previsão neste sentido, nem se pode considerar existente "um princípio geral implícito de equilíbrio contratual". Assim, o instituto influi em uma relação sinalagmática, cujo equilíbrio subjetivo se projeta no contrato. Do contrário, as próprias execuções das obrigações seriam imponderáveis, pois se teria um cenário de desequilíbrio contratual a cada instante. Ademais, há aquelas circunstâncias

93 Fator que, novamente, nos reconduz ao que dispõe o art. 112 do CC. 
inerentes à própria álea do negócio, que excluem a possibilidade de revisão. $\mathrm{Na}$ existência de um princípio geral, a álea violaria tal princípio. No entanto, ela é conditio sine qua non para firmar contratos empresariais.

Informação bibliográfica deste texto, conforme a NBR 6023:2018 da Associação Brasileira de Normas Técnicas (ABNT):

HEINEN, Juliano; SOARES; Leonela Otilia Sauter. A estrutura teórico-dogmática do equilíbrio contratual no direito privado - Pode ser ele considerado um princípio geral do direito? Revista Brasileira de Direito Civil - RBDCivil, Belo Horizonte, v. 28 , p. $15-42$, abr./jun. 2021.

Recebido em: 04.08.2019

1으 parecer em: 17.07.2020

2ำ parecer em: 30.07.2020 